\section{Boston College Law} School gets new library Boston College's Law School has opened a new $\$ 11.7 \mathrm{mil}-$ lion library on the 40 -acre Newton campus. The new library, clesigned by Earl $\mathrm{R}$. Flansburgh \& Associates, represents the first phase of a four-phase, 10-year replacement program of the Law School's facilities

"We wanted this building to be a center for learning, for interaction, and for legal scholarship," said law library director Sharon Hamby O'Connor. "Our law library achieves all three exceedingly well." The library is designed to hold a projected print collection of 348,000 volumes and can accommodate study space for up to 530 students and faculty. Other features include a computer center and legal research lab, private study rooms, audiovisual equipment, state-of-the-art computer networking, and structural design to accommodate both open and high-density shelving systems. The four-level library is composed of four wings organized around a central atrium; student and faculty areas are integrated throughout the four levels. residency program on the IU campus. Together Walclen and IU created an information support system that offers distributed learning to Walden students throughout the country.

Julie Bobay, head of IU's Electronic Resources and Services Department, has been appointed the first Walden Endowed librarian. Bobay sees "acadenic libraries ... at a critical point in their history. . . The digital library will, at least in theory, distribute scholarly information to students and teachers regardless of their physical location. The implications are quite profound."

\section{Another discussion topic for Midwinter}

The topic of the ACRL University Libraries Section's Librarians in Higher Eclucation and Campus Administration Discussion Group will be "Multiplicity: Librarians in New Campus Roles." The group meets Sunday, February 16, from 9:30-11:00 a.m. during the ALA Midwinter Meeting in Washington, D.C.

\section{Walden Univ. endows li- brarian position at Indiana} Walden University in Minneapolis has pledged $\$ 500,000$ to the Indiana University (IU) Libraries to establish and permanently fund the position of Walden Endowed Librarian. This is the first endowed library position in IU's 176-year history. Walden University is an accredited, independent distance education university offering Ph. D. programs for the mid-career "scholar-practitioner" in the fields of administration management, education, psychology, health services, and human services, as well as an Ed.D. and master's in education. In 1992 IU Libraries began providing information support to Walden students in their summer

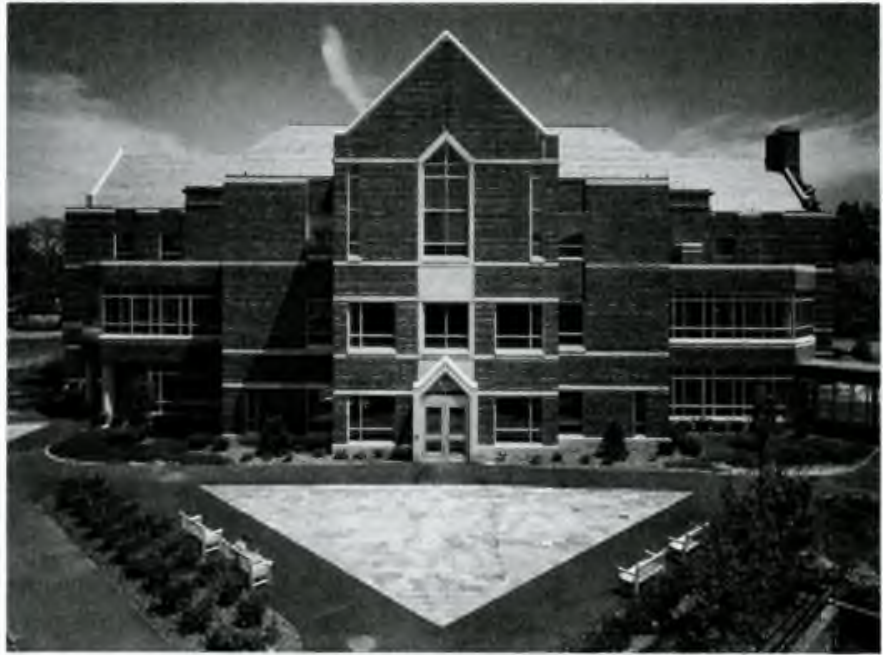

The new 84,500-square-foot Boston College Law School Library is fully wired with power and data hook-ups for every reading table, study carrel, window bench, and group study and lounge seat within the facility. 


\section{"European Links": WESS preconference offers survival aid for European selectors}

An intensive seminar for librarians with selection responsibilities in Western European studies is being offered by ACRL's Western European Specialists Section (WESS). Entitled "European Links: Sources of Information in Western European Studies for Academic Libraries," the 1997 WESS preconference will take place in San Francisco on June 26 and 27. "European Links" offers basic survival assistance - and even some advanced skillsto librarians responsible for choosing library materials from Western European countries.

Once the preserve of faculty or specially trained subject specialists, the selection of books, journals, documents, and other important library resources from France, Italy, Spain, Germany, the Netherlands, or Scandinavia is today often just one more duty thrust upon busy librarians in reference and technical services. Even trained selectors and collection management librarians find themselves in this difficult situation if their expertise is in one area, but they are assigned to purchase materials in another. How do you select responsibly and cost-effectively-or monitor and augment faculty selections - in languages in which you lack proficiency and for countries and cultures you do not know - and attend to your 20 other areas of responsibility?

"European Links" answers this need. In workshops and plenary presentations, experienced bibliographers and acquisitions specialists will offer concise, practical, expert training in dealing with both the big picture and the day-to-day issues of Western European materials selection, regardless of participants' language or subject background. You will learn how to identify and acquire the most important titles now being published in Western Europe, to create knowledgeable and controllable approval plans, and to assess existing collections and mount intelligent retrospective purchasing efforts compliant with tight budgets.
"European Links" begins on Thursday evening, June 26, with a reception and keynote address at San Francisco's Goethe House, followed by a full day of workshops in an ALA conference hotel on Friday, June 27. There, WESS experts will discuss the most accessible bibliographic and reviewing sources, available vendor services, resources on the Internet and World Wide Web, and some of the scholarly traditions and publishing practices in European countries that differ from the more familiar North American arrangements.

Speakers and workshop leaders will be Richard D. Hacken (Brigham Young University), Peter Allison (University of Connecticut), Heidi L. Hutchinson (University of California, Riverside), Jeffry Larson (Yale Uni-

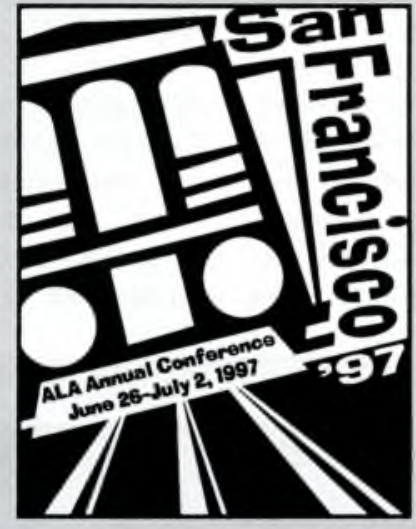
versity), Jeffrey Garrett (Northwestern University), Dan C. Hazen (Harvard University), Mary Jane Parrine (Stanford University), and Mariann Tiblin (University of Minnesota). In addition, many leading European booksellers and vendors will be present to describe their services.

The registration fee, which includes a reception and coffee breaks as well as all official preconference events, is $\$ 95$ for ACRL members, $\$ 130$ for members of ALA, and $\$ 185$ for non-ALA members. (Students pay $\$ 50$.) The deadline for registration is May 15, 1997. Participation in "European Links" is limited to the first 75 applicants, so early registration is advised.

For further information about the content please contact the program planner, Eva Sartori, University of Nebraska-Lincoln, at (402) 472 6987; e-mail: evas@unlib.unl.edu. For questions about registration or to request a registration form, please visit WESS's Web site, WESSWeb, at http://www.library.nwu.edu/collmgmt/humanities/wessprec.htm or contact Mary Ellen Davis, ACRL, 50 East Huron St., Chicago, IL 60611-2795; (800) 545-2433, ext. 2511; fax: (312) 280-2520; e-mail: medavis@ala.org. 


\section{Volunteers needed for ACRL Nashville conference}

Here's an opportunity for a new professional development experience. Try volunteeringit's your opportunity to meet new people, expand your network of colleagues, and give back to the profession. Volunteers are needed to help out at ACRL's 8th National Conference in Nashville, April 11-14, 1997. You need not be from the Nashville area to help out. Volunteers

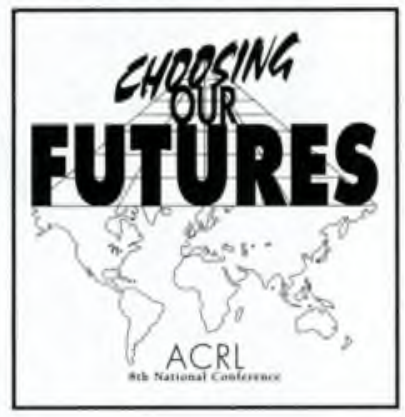
are needed for such jobs as meeting room assistants, Internet room assistants, and preconference assistants.

To volunteer contact the Local Arrangements Committee cochairs, Shirley Hallblade, hallblade@library.vanderbilt.edu, or Bill Robnett, robnett@library.vanderbilt.edu. Note: Volunteers must register and pay regular conference fees. Details about the conference may be found in the January issue of CERL Neus and on the Web at http://www.ala.org/acrl.html (then select National Conference). Advance registration continues through March 7.

\section{World Almanac added to OCLC's FirstSearch}

The World Almanac and Book of Facts from K-III Reference Corporation (formerly Funk \& Wagnalls) is now available on the OCLC FirstSearch Service. Citations in the World Almanac database include the complete full text of a section or subsection represented in the printed World Almanac, including tables. The database will be updated annually. Among other K-III titles to be mounted on FirstSearch are: The World Almanac of the U.S.A., The World Almanac of U.S. Politics, and several children's almanacs.

\section{Ancient manuscripts put on the Web}

Experts at six institutions with extensive collections of papyri are preparing the texts that shed light on ancient Greek and Egyptian life for the Web. The effort known as the Advanced Papyrological Information System (APIS), unites scholars at Columbia, Duke, Princeton, and Yale Universities with the Universities of California at fall.

Berkeley and Michigan. The six collections contain some 30,000 items, about 10 percent of the known papyrological archives worldwide, and consist of documents from daily life-tax records and legal files - as well as literary works. The majority of surviving texts are from the late 4 th century B.C. to the middle of the 8th century A.D. The team, led by Roger Bagnall, chair of Columbia's Classics Department, hopes over the next four years to produce an innovative electronic catalog with links to images, bibliography, text, and published literature. An initial step will be to catalog, conserve, and digitally image boxes of materials that have in some cases lain undisturbed for 30 years or more. An early version of APIS is to be available next

\section{Supreme Court decisions on Web}

U.S. Supreme Court decisions from 1937 through 1975 are now available online via GPO Access, the online information service provided by the U.S. Government Printing Office. The full-text database of the high court's decisions for that 38-year period is being provided by the Office of Regulatory Affairs of the Office of Management and Budget as a finding aid to the official version of the United States Reports. The database is fully searchable on the Web at http: //www.access.gpo.gov/su_docs/supcrt/. User assistance is available by e-mail: gpoaccess@ gpo.gov; phone: (888) 293-6498 (toll free).

\section{Soaring to Excellence series continues}

The 1996 Soaring to Excellence teleconferences for library paraprofessionals produced by the College of DuPage in Glen Ellyn, Illinois, were so successful, attracting more than 10,000 participants at more than 400 sites, that a brand

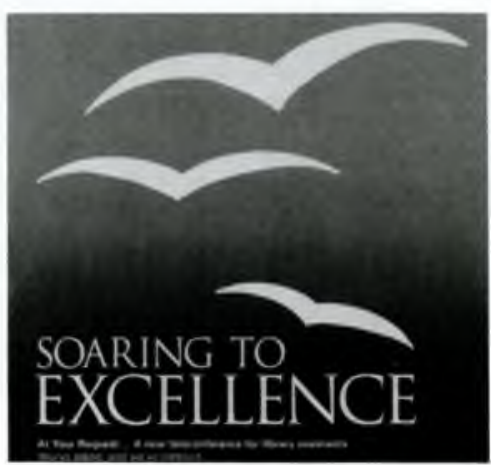

day, February 14, noon to 3 time. new series will be broadcast in 1997. The theme of the 1997 series, "At Your Request," stresses the importance of library assistants in the workplace and as individuals. The series consists of:

- You and the Internet, Fri- 
- You and Technical Services, Friday, March 14, noon to 3:00 p.m., Eastern time.

- You and Your Job: Body, Mind and Spirit, Friday, April 11, noon to 3:00 p.m., Eastern time.

The teleconferences can be taken for college credit or continuing education units through the College of DuPage. Live video hook-ups to some participating sites will allow attending library assistants from different parts of the country to be both seen and heard during the broadcasts. For information on becoming a participating site call (800) 3LINKUP ( 800 354-6587) or e-mail: slusar@cdnet.cod. edu. Visit the Soaring homepage at http:/ www. clupage.edu/soaring.html.

\section{Teleconference on electronic resources}

The College of InPage is also broadcasting a two-part teleconference for library professionals called "Dancing with . . . Change: Electronic Libraty Resources: Issues and Opportunities." The broadcasts are Fridays, February 28 and April 4, 1997, and feature Michael Goman, dean of library services at California State University in Fresno, along with Betsy Baker (Northwestern University), Walt Crawford (RLG), Paula Watson (University of Illinois), and others. Site registration is $\$ 395$. To register or for details call (800) 3LINKUP; or register by Internet: http: www dupage.edu/dancing. html.

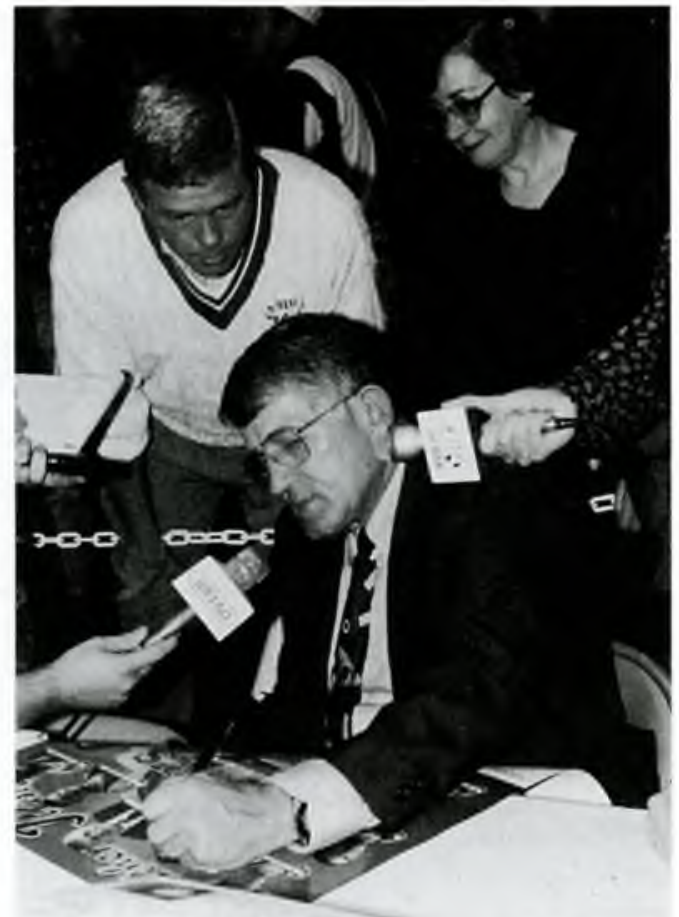

Southern Illinois University raises library awareness through its athletic program. Basketball Coach Rich Herrin signs posters for fans at a benefit game for the libraries as library dean Carolyn Snyder and athletic director Jim Hart look on.

\section{Ohio State Univ. at Marion opens} new campus library

A new $\$ 7.1$ million libraty or the Ohio State University's Marion Campus increases campus library space fourfold with 24,000 square feet of floor space and housing for 37,000 volumes and 250 journals. The building was designed by Moody \& Nolan LTD. of Columbus. The facility features an expansive rotunda with attractive landscaping to complement views of a campus pond and meadows from the library rotunda, offices, and mezzanine.

\section{New systems installed}

These institutions have selected new automation systems:

- Johns Hopkins Univer sity selected the Horizon sys- 


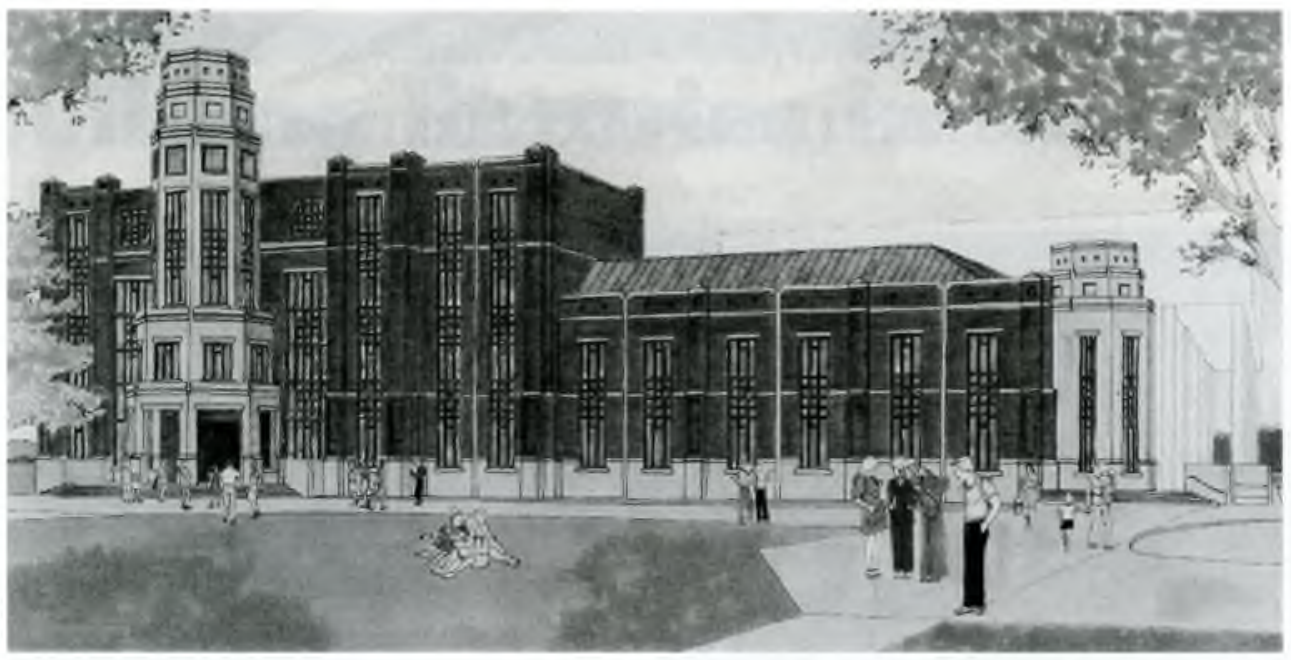

An architect's rendering of the planned $\$ 20$ million Loyola University New Orleans $\mathbf{L}$,ibrary.

tem from Ameritech Library Services;

- Acadia University in Wolfville, Nova Scotia, selected SIRSI's Unicorn system;

- Dordt College in Sioux Center, Iowa, selected SIRSI's Unicorn system.

\section{Bowling Green cooks}

Bowling Green State University's Jerome Library has published A Taste of Jerome: 30th Anniversary Commemorative Cookbook. The cookbook features more than 150 recipes from library staff and friends, descriptions of the library collections, and anecdotes. Copies are available for $\$ 7.00$ plus $\$ 1.50$ shipping/ handling. Send your check, payable to Bowling Green State University, to cookbook, Jerome

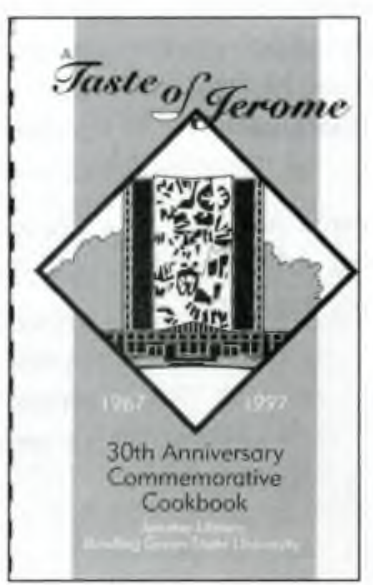

Library, Rm. 222, Bowling Green State University, Bowling Green, OH 43403. Profits from the sales will be used to enhance the library's collections.

\section{Loyola University New Orleans launches $\mathbf{\$ 5 0}$ million campaign}

Loyola University New Orleans launched "Thresholds," a \$50 million capital campaign for the construction and endowment of a new 150,000-square-foot, state-of-the-art library, en- dowment of student financial aid, and faculty endowment. A groundbreaking ceremony for the new library was held in late November.

Special features of the new library include space for a collection of 550,000 printed volumes, computer network access at every table and carrel, more than 100 public computer workstations, three microcomputer labs, two multimedia classrooms, a classroom for teaching the use of technology for study and research. and a literacy center. The new J. Edgar and Louise S. Monroe Library, which will cost more than $\$ 20$ million to construct and equip, is named after Loyola's largest benefactor who before his death pledged $\$ 7.5$ million to support construction. Architects for the project are the Mathes Group. Construction began in December and is scheduled to be completed in Octoler 1998.

\section{Share your opinion with C\&RL News readers}

CERL Neus is looking for well-reasoned commentaries on issues of interest to academic and research librarians for its column, "The Way I See It." This is an opportunity to share your thoughts with a national audience. Essays should be between $500-750$ words and should be sent to "The Way I See It," CERI Neus, ACRL, 50 E. Huron St., Chicago, IL 60611-2795; fax: (312) 280-7663; e-mail: medavis@ala.org. 


\section{WHY DO 6,000 LIBRARIES IN 44 Countries use OCLC FirstSearch?}

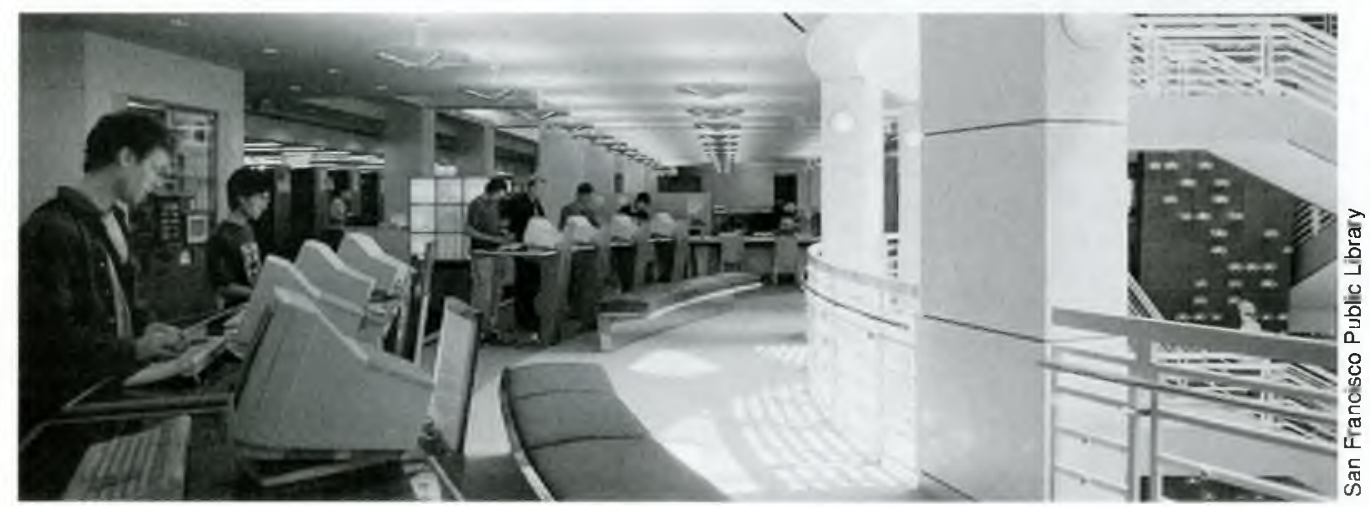

\section{FIRSTSEARCH}

\section{COMPREHENSIVENESS}

- oclC World Cat, the most frequently consulted database in higher education

- New York Times, the most recent 90 days of articles with abstracts since 1994

- FirstSearch Ca Student Edition, a customized Chemical Abstract Services collection for undergraduates (coming in 1997)

- OClC FirstSearch EleCtronic COLlections ONLINE, a critical mass of scholarly journal articles (coming in 1997)

- OCLC NetFirst, unparalleled subject access to Internet resources

- Nearly 60 other databases covering humanities, science, social studies and more
FIRSTSEARCH

Full-TeXT

- More than 1 million newspaper and journal articles for immediate online viewing or e-mail delivery

- Electronic reference files: encyclopedias, almanacs, phone books, directories, financial reports

- Patron generated fulltext document delivery via interlibrary loan, fax and mail

http://www.oclc.org/

\section{FirstSearch}

FleXibILITY

- Seamless integration with your collection, LAN, Web services, ILL, online full text and document delivery

- Mix and match databases, full text, access level and payment plans to best serve the needs of your users

- Choice of TTY, Web or Z39.50 interface options

- Affordable pricing options: per-search or subscription, individual or group 